University of Louisville

ThinkIR: The University of Louisville's Institutional Repository

Electronic Theses and Dissertations

6-1916

\title{
The attitude of the Romantic poets towards nature.
}

Margaret Jane Wanless

University of Louisville

Follow this and additional works at: https://ir.library.louisville.edu/etd

\section{Recommended Citation}

Wanless, Margaret Jane, "The attitude of the Romantic poets towards nature." (1916). Electronic Theses and Dissertations. Paper 1526.

https://doi.org/10.18297/etd/1526

This Master's Thesis is brought to you for free and open access by ThinkIR: The University of Louisville's Institutional Repository. It has been accepted for inclusion in Electronic Theses and Dissertations by an authorized administrator of ThinkIR: The University of Louisville's Institutional Repository. This title appears here courtesy of the author, who has retained all other copyrights. For more information, please contact thinkir@louisville.edu. 
THE ATIITUDE OF THE ROMANTIC POETS TOWARDS NATURE.

$$
--\infty 00--
$$

THESIS

\section{SUBMITTED TO}

FACULTY OF UIIVFRSITY OF IOUISVIIIE.

\section{BY}

MLARGARET JANE WANLESS

CANDIDATE FOR DEGREE OF

WASTEER OF ARTS.

JUNE 1916: 
THE ATTITUDE OF THE ROMANIIC POETS TOWARDS IJATURE.

$$
---000-\cdots
$$

(An attempt to portray the different roles that nature has played in the poetry of Wordsworth, Coleridge, Shelley, Keats and Byron.?

By nature I mean the wide world of eye and ear that surrounds man, the kinship of which to man, it has been the poet's privilege to interpret. Each poet interprets differently because each sees through different glasses.

$$
\begin{aligned}
& \text { "We receive but what we give, } \\
& \text { And in our Iife alone does nature live." } \\
& \text { (Coleridge - Dejec. 4 - I.) }
\end{aligned}
$$

Nature has been truly called a "maker of poets". Had she not used her magic wand, we should have had no wordsworth with his appreciation of the meanest things of life; no shelley with his lark songs; no Coleriage with his glorious "Hymn to int. Blanc"; no Keats with all his wild flowers; no Byron with his love of ealm and raging sea. She made them all what they are and yet, how different.

In every one we find the same love of mountain, lake and stream, night and stlence, the moon, and the night-in-gale. In all, except perhaps Wordsworth, we feel the true Englishman's love of the sea, calm, blue and beautiful, or wild and terrible. Wordsworth seems to have felt it; but calis it the "joyless ocean." (When to -84. )

In Wordsworth, Keats, Shelley, Coleridge, we meet the little lowly inglish wild-flowers, - the primrose, the violet, the musk-rose, the dalsy, the forget-me-not, and the whole host of others that if we do not already know; we learn to love in reading them.

Yet each of these poets introduces us to the flowers in his "own sweet way." Wordsworth make's us see them just as they are, no more beautiful, jet each perfect in its way. coleridge and Shelley clothe them with wonderful imagery. - Keats has us to see, hear, smell and taste them.

"And one coy primrose to that kock The vernal breeze invites."

$$
\therefore \text { (Words. - The Prim. of - 6) }
$$

"That blue and bright-eyed floweret of the brook, 
Hope's gentle gem, the sweet Forget-me-not." (Coleridge - The Keepsake - 12)

"I saw an arbour like a drooping roof of trellis vines and bells, and larger blooms, Iike floral censers swinging light in air."

$$
\text { (Keats - Hyp. A Vis. - 25) }
$$

"Daisles, those pearled Arcturi of the earth The constellated flower that never sets." (Shelley - The Ques. - 2 - 2)

The lark and the night-in-gale sing for us in the same way, a different song for each.

Byron shares with the rest the appreciation and love of the fierce, tremendous side of nature, - the Alps, the sun, lightning, thunder, rain, and sometimes even the twilight, the stars, and silence.

Each needed nature as a haven from contact with men of coarser mold and jet the necessity of this solace to each was different, as his regard towards mankind differed. Byron, and Wordsworth in his early life, regarded nature as absolutely perfect except for man. Han seemed in his imperfections, to have been, especially for Byron, a blot on the landscape.

"Have I not reason to lament

What man has made of man?"

(Words. - Iines in E.S. - 23)

"Is it not better thus our lives to wear

Than join the crushing crowd, doomed to inflict or bear?"

$$
\text { (Byron - Ch. H.P. - IXXXI - 9) }
$$

Coleridge did not seem to wish to leave man entirely out-side when he communed with nature. We find always the thought of man, there, but not as in Byron, as an intrusion on nature. In the deepest solitude, he thought of man and wished to help him.

Shelley makes man a part with all the rest of nature as Wordsworth does when he is older and has heard "the still sad music of humanity".

"He 18 made one with nature"
(Shelley - Adonais - XIII.)

Thoy all seem to fool and oarse us to foel the oternity of nature and the paseing moment of man.

In each, there is the hope of some kind of immortality. God for each one is different just as all other things 
are. With Wordsworth, God and nature seemed almost one. With Shelley, God is man's enemy, nature his mother. With Coleridge, all nature was made by God for man as a great glory to God. With Byron, we cannot quite tell, although one gets the impression that God and nature are good and in accord, but man is a discord.

Iif purpose, in this thesis, is to discuss each of these five poets in turn, bringing out the different way in which each has regarded nature and also the common points that they have loved in her. 
WORDSWORTH AND NATURE.

$--000--$

"His daily teachers had been woods and rills."

(Brougham - 162)

Wordsworth is said to have seen and to have had man see nature as she really is, more truly than any other poet. He says,

$$
\begin{aligned}
& \text { "I called on both (earth and sky) } \\
& \text { To teach me what they might." } \\
& \text { (Prelude - } 3-112 .)
\end{aligned}
$$

They taught him and he taught us.

Wordsworth, however, did not seem to feel the relentless fatefulness of nature as Tennyson for instance, saw it. He looked on her as a mighty whole, beautiful in each little detail. He has the same quiet touch, true and unerring, that Hardy has in later years in his prose, handling the rough common subjects of life with the same skill that others display in writing of the grand and marvelous. To him, the gorgeous sunset, the wonderful castle, imposing mountains, the unfinished sheep-fold, the daisy in the field, the little patch of stars above, are all parts of God's wonderful world, each important in its way.

Nature secms to have played a peculiar role in the development of Wordsworth, the man and poet, however. In his youth even at the early age of nine, he seems to have considered man a blot on the landscape. At that time, he was completely overpowered by nature., "The first virgin passion of his soul." (Excurs: $I-285$ )

He tells us in "Tintern Abbey" that in his love for nature at first he was more like one

"Flying from something that he dreads than one Who sought the thing he loved."

$$
\text { (Tintern A. - } 72 \text { ) }
$$

Nature was to Wordsworth a great, wonderful passion, beautiful in itself alone, each little separate part worth while and great in itself. She seems to have been absolutely perfect except for "what man has done to man."

"To her falr soul did nature link The human soul that through me ran And much it grieved my heart to think What man has done to man."

$$
\text { (Iines Writ. in E.S.-6) }
$$


"Oh, leave me to myself nor let me feel The officious touch that makes me droop again." (Early Youth - 14)

With the fervor of youth, the animal passion passed, however, and the love remained, but the man began to look on nature as hearing oftentimes

"The still sad music of humanity."

ITintern Abbey - 91)

He writes -

"I found

"Once more in man an object of delight."

(Prelude $13-49$ )

Then he began to study man.

"For present Iife in life's familiar face."

(Prelude 13 - 62)

"He loved to watch the road that crossed

The naked summit of a far-off hill."

(Prelude 13 - 148)

and study the people that trod it. The lonely road became an "open school" in which he might daily read the passions of mankind. He began to see the depth of human souls that seemed to the naked eje to have no soul. He understood and loved the lowly shepherd folk about him. The place he knew best was. "Sheep-selling Cockermouth." as he calls it.

He mentions, often even describes, the dwelling of the poor, not in a way to make one pity but almost envy them.

"Here on the brown wood cottiages they sleep."

(Desc. Sket. 214)

"Where deep and low the hamlets lie

Beneath their little patch of sky

And little lot of stars."

(P.B. 228)

"Yon cottage seems a bower of bliss."

(Yarrow V. - 6I)

"Every mortal feeling" of his soul

Strengthened and braced by breathing in content -......--the wholesome air of poverty." (Excurs. I - 306)

"The 0ld Cumberland Beggar", himself was worth while.

As a result of his study of man, later in life Wordsworth even makes a bright contrast between man and bird.

"Iike those aspirants let us soar - our alm

Through life's worst tridis whether shocks or snares

A happier, brighter, purer heaven than theirs."

(Where lies the Iruth? - 12) 
So to the light of setting suns, the round ocean, the living air, the blue sky" was added "the mind of man."

Nature to Fordsworth was just a great teacher and a delightful solace. He do not find in any of his works the inexorable, futeful, relentless law that characterizes the nature of some of the later poets. She was his nurse, his guide, the guardian of his heart and soul of all his moral being. "Tis her privilege

Through all the years of this our life to lead From joy to joy."

$$
\text { (Tintern Ab. - 104) }
$$

She can so teach us that no matter how harshly men may deal with us in the ordinary dreary intercourse of daily life, we can still see a blessing in all things.

Wordsworth feels God in all.

"His mind was a thankagiving to the power

That made him; it was blessedness and love." (Excurs. 1 - 217)

"In the mountains did he feel his faith

All things here breathed immortality infinite." (Excurs. 1 - 226.)

"One adequate support for the calamities of life exists iaith absolute in God." .

$$
\text { (Ixcurs. } 4-22)
$$

Wordsworth feels as all great poets seem to have done, the everlastingness of nature as compared to the brief life of man :-

"Holds up before the rind intoxicate

With present objects and the busy dance

of things that pass away, a temperate show

of objects that endure."

$$
\text { (Prelude }-13-32 \text { ) }
$$

Fancy plays a great part with every poet in his treatment of nature or rather, in her treatment of him. Even Wordsworth who made the little things of life appear so much as they really are, says -

"I had a world about me - 'twas my own;

I made it, for it only lived to me."

$$
\text { (Prelude } 3 \text { - 142) }
$$

He made it live for us however, in all its simplicity, but with Wordsworth's appreciation added to it.

Han's fancy makes the raven croak of death; the ow forebode mishap; the whip-poor-will voice the spirit of the toll worn slave etc., but even fancy for Wordsworth cannot sadden the song of the lark, "the happiest bird out of Paradise." 
dear old robin-redbreast, the "harbinger of everlasting spring" are doing their little work in his world. bosom of eternal things." (Clouds - 94)

He has the same love of the moon as a companion in his lonely nights that are not lonely, that all the other poets have.

However, he seems to have lacked the natural deep love of the sea that the island-born Englishman usually has.

"Back to the joyless ocean thou art gone." (When to. - 84l

again -

What a contrast to Byron and lennyson. He says

"Of the old sea.

Some reverential fear is with me."

So we find this gentle man, all poet loving everything in nature, at last even man and the poor man at that, feeling God in ali and making us glad to be alive in "God's beautiful world."

He writes -

"As in the eye of nature he has lived

So in the eye of nature, let him die."

(Cumberland Beggar - 197)

but Wordsworth and his nature poetry cannot die as long as the linglish tongue continues to be read and spoken. 


\section{COLERIDGE AND NATURE.}

In Samuel raylor Coleridge's "Hymn to Mt. Blanc", we find his conception of nature -

"Earth with her thousand voices praises God." (Fymn to Mt. Blane. - 85)

As Wordsworth says, all nature is speaking to us everywhere, if we will only stop to hear and each man makes his own nature-world. To Coleridge, all nature seems to have been one great voice shouting "God". He saw God's work in everything. It was to him just all one great proof of God's wonderful sovereignty and, as in the grand hymn to Mt. Blanc, should speak God's praises and be one great paean to Him the All God, All Powerful, All Terrible.

"Sing ye meadow streams with gladsome volce." ( Hymn - 60)

"And they too have a voice, yon piles of snow And in their perilous fali shall thunder, God." (Hymn - 62)

"Ye flowers, -.. wild goats -.. eagles -.-lightnings signs and wonders of the elements

Utter forth "God", and fill the hills with praise." (Bymn - 64)

He is not a pantheist but has no judgment to pass on him who sees God everywhere. Iines - 34

"...... so shalt thou see and hear

of that eternal language which thy God

Utters, who from eternity doth teach

Himself in all, and all things in himself.

Great Universal Teacher! He shall mould

Thy spirit, and by giving make it ask." (Frost at Midnight - 58)

prayers to God.

Nature blended always with his thoughts of God and

In his "Answer to the Child's Question", he says "I Iove my Love and my Love loves me." (Ans. to $C .2 .-10$ )

Nature was his lore, but she was the rolce of God to man. He enjoyed nature to the full with a reverent solemn joy, felt God pervading every part of her. In his description of the "Valley of Seclusion" as he was leaving it he writes: - "God, methought, had built him, there, a temple: the world seemed imaged in its vast circumference.

It was a luxury - to be :"

(Reflections - $3 \dot{8})$ 
For him, nature was meant as a rest. He loved to stay. with her but not in Byron's wild, passionate way. He felt his duty towards man, constantly. Always in the most delightful musings on nature, man.intruded and yet we do not feel him altogether an intrusion. He could not enjoy even so rare a pleasure as a flower-bloom in the open in February without comparing it to the shortness of beautiful youth and hope.

Wordsworth, we feel, reasoned Nature - God - Man; Coleridge - God - Man - Nature.

The voice of the night-in-gale, "the minstrel of the moon" seemed to him not so sweet as the voloe of her "best loved of human kind." (To the Nightingale - 24)

Always with Coleridge, after God, comes humanity. Companionship is good for man, he thought and nature is his great healer, solace, and teacher. Society seemed worthwhile, - conversing with the mind and giving it.

"A livelier impulse and a dance of thought."

(Fears in Sol. - 205)

"Grateful that by nature's quietness

And solitary musings, all my heart

Is softened and made worthy to indulge

Love and the thoughts that yearn for human kind."

(Fears in Sol. - 224)

Iike Wordsworth, he loved the simple things of life. Riches seemed futile to him and the little cottage and roses more to be desired than much fine gold. A simple cot, vines, roses, the river, seemed "bliss enow" to him. He says - "Sweet abode? Ah! - none greater! and that all had such!" (Reflections 69)

"Low our pretty cot! our tallest rose

Peeped at the chamber window. (Reflec. - 1)

$n$

A wealthy son of commerce saunter by, Bristowa's citizen; methought it calmed his thirst

of idle gold and made him nuse

With wiser feelings. (Reflec. - 9)

Again he speaks of "my own lowly cottage". (Pears in Sol. 220)

All the little simple parts of nature spoke to him just as they did to Wordsworth but his. fancy always clothed them with some imagery. Just his bold, clear way of expressing things and the strong words he uses gives one a wonderful picture

"Nor dim nor red like God's own head

The glorious Sun uprist."

(Rime of a M. $-2-18$ )

So great a force was nature in his life that he con- 
tinually personifies her. He makes every part of her live.

He cannot write of nature as seen in the "common people". His sphere is always the supernatural but his elements, the natural. No man for whom nature had not lived could have used her as he does in the "Rime of the Anclent Mariner." The sun, the sea, the moon are all living moving beings, part of life and existence.

"The sun came up upon the left

Out of the sea came he!

And he shone bright and on the right

Went down into the sea."

(Rime of A.M. 1 - 25)

Again writing of the Storm-blast -

"As who pursued with yell and blow."

(Rime of A.M. I - 46)

"It cracked and growled and roared and howled."

(Rime of A.M. 1 - 6I)

"Bloody Sun --- above the mast did stand."

(RIme of A.M. 2 - 30)

Again -

"The western wave was all aflame!"

(Rime of A.M. 3. -29)

"The stars rush out

At one stride comes the dark."

(Rime of A.M. $3-57$ )

In his description of the moon -

"The moving moon went up the sky."

(Rime of A.M. 4 - 94)

"The wan stars danced between."

(Rime of A.M. 5 - 26)

Iike Wordsworth, Coleridge feels silence to be a great force in nature -

"Alone, alone, all, all alone

Alone on a wide, wide sea:

So Ionely 'twas that God himself

Scarce seemed there to be."

(RIme of A.M. 4 - I)

"The moonlight steeped in silence."

(RIme of A.M. 6-69)

"The bay was white with silent light."

(Rime of A.M. $6-71$ )

"The silence sank

Ilke music on my heart."

(Rime of A.M. $6-89$ )

"A green and silent spot amid the hills.

$A$ frigll and silent dell. O'er stiller place

No singing skylark ever poised himself."

(Fear in sol. 1) 
"Tis a quiet spirit-healing nook."

(Fear in Sol. 12)

"Remembering thee, 0 green and silent dell!"

(Fear in Sol. 223)

"And after lonely so - journing in such a quiet and surrounded nook."

(Fear in Sol. 208)

"O soft and silent spot

On the green sheep track up the healthy hill."

- Fear in Sol. 203)

Coleridge feels also the volce of the wind and the tremendous place he plays in nature. In describing the wind coming in a storm, he writes. -

"What a scream sent forth."

Of agony by torture lengthened out that lute

(Dejec. 7 - 4)

He calls the wind the "Mad Intanist."

"Mak'st Devil's yule, with worse than wintry song." (Dejec. 7 - 13).

"Thou actor perfect in all tragio sounds!"

(Dejec. 7 - 15)

In Coleridge, we find the true Englishman's love of

the deep - "God be with thee gladsome Ocean."

(On Re. Sea - S - I)

Again -

"We could hear

At silent noon and eve and early morn

The sea's faint murmur."

(Reflec.2)

"Ye Ocean Waves that wheresoe'er ye roll

Yield homage only to eternal laws."

(France 3)

he writes -

In speaking of the stars and moon which all poets love,

"I see, not feel, how beautiful they are!"

(Dejec. 2 - 18)

He finds melancholy in nature. He had a happy way from youth of throwing fancy into everything and making himself happy whether or no. He calls this faculty "lly shaping imagination." (Dejec. 6 - II)

The night-in-gale which Milton named "most musical, most melancholy bird", he speaks of -

"Tis the merry night-in-gale."

(The Nightingale 43) 
He says there is really nothing melancholy in nature; but man who has known grief finds it in the things about him because he puts it there. In ballerooms and hot theatres, youths and maidens heave sighs over the melancholy strain of the night-in-gale which he declares is really joyous.

This poet feels a healthy scorn for those who prefer the "intricacies of labored song" in a concert room to "Hature's passion warbled plaint."

(Iines Compos. in C.R. 6)

He loved also the "singing skylark" as he calls it "O singing skylark That singest like an angel in the clouds." (Fears in Sol. 27)

" That sings unseen

The minstrelsy that solitude. loves best." (Fear in Sol. 17)

The little flower, the tinkling rill, the birds, the hills, the mountains and man-kind were alike dear to Coleridge each fulfilling a part in the life of the universe and God directing all.

"A man who would fain preseirve

His soul in calmness, yet perforce must feel For all his humam brethren."

(Fear in Sol. 30 ) 
SHEILEY AND NATURE.

$--000--$

Nature to Shelley meant more than she did to Wordsworth, Coleridge, Keats or Byron. He calls her "Mother of the unfathomable world." He also, writes of Mt. Blanc, but for him the mountain sings no hymn to God, but is just all nature, sufficient in itself. It stands for eternity and power in itseif not for the praise of the God of Coleridge.

Shelley is a real pantheist. Everything about him was God. In his address to the "Spirit of Nature" in "Queen Mab", he writes -

\author{
"Spirit of Nature! hore! \\ In this interminable wilderness \\ of worlds at whose immensity \\ Even soaring fancy staggers, \\ Here is thy fitting temple."
}

He considered nature as one with man, however, not as Wordsworth as more beautiful and apart from man, but each as a phase of the great whole. He calls her the "Great parent."

Iike Coleridge, Shelley loved mankind and was continually brooding over man's troubles, not considering them as Wordsworth did in his youth and Byron did - a blot on the landscape; but just one little portion of the nature that is altogether. harmonious except for man whose troubles break in on the harmonious whole and cause a discord. He has a sword that takes away nature's peace, he grinds down the poor with an instrument still more dreadful than a sword. All the rest of nature is kind to rich and poor alike. The sun shines on the cottage as brightly. as on the palace and the good rain falls for all.

"The fruits, the flowers, the trees Arise in due succession; all things speak

Peace, harmony, and love. The universe

In nature's silent eloquence, declares

That all fulfil the works of love and joy -

All but the out-cast man."

(Queen Hab - 3 - 194)

Nevertheless, Shelley has hope for man and in this hope be strives. He is continualiy trying to find a way out for humankind: Man's lack of freedom, want of love for fellow-men, and all the other troubles of the human race are brought out in almost every Iine of "Prometheus Unbound", but the spirit of nature pervades the whole and shelley finds hope for man in the perfection of other parts of the great universe. 


\section{"Iike their's his age of endless bliss Which time is fast maturing Will swiftly, surely come." \\ (Queen Mab $3-235$ )}

Shelley falls back, just as all the other poets do, on nature as a solace and a joy, a hope and comfort when man's troubles get past endurance. Nature is his religion, his God. Even man, he concludes, finally becomes one with nature and a part of her. After what we call death, man is as free and as good and as immortal as the other forms of nature.

"He is made one with nature; there is heard

His volce in all her music."

\section{(Adonais XIII)}

The transiency of things mortal preys on his mind just as it does on that of Wordsworth -

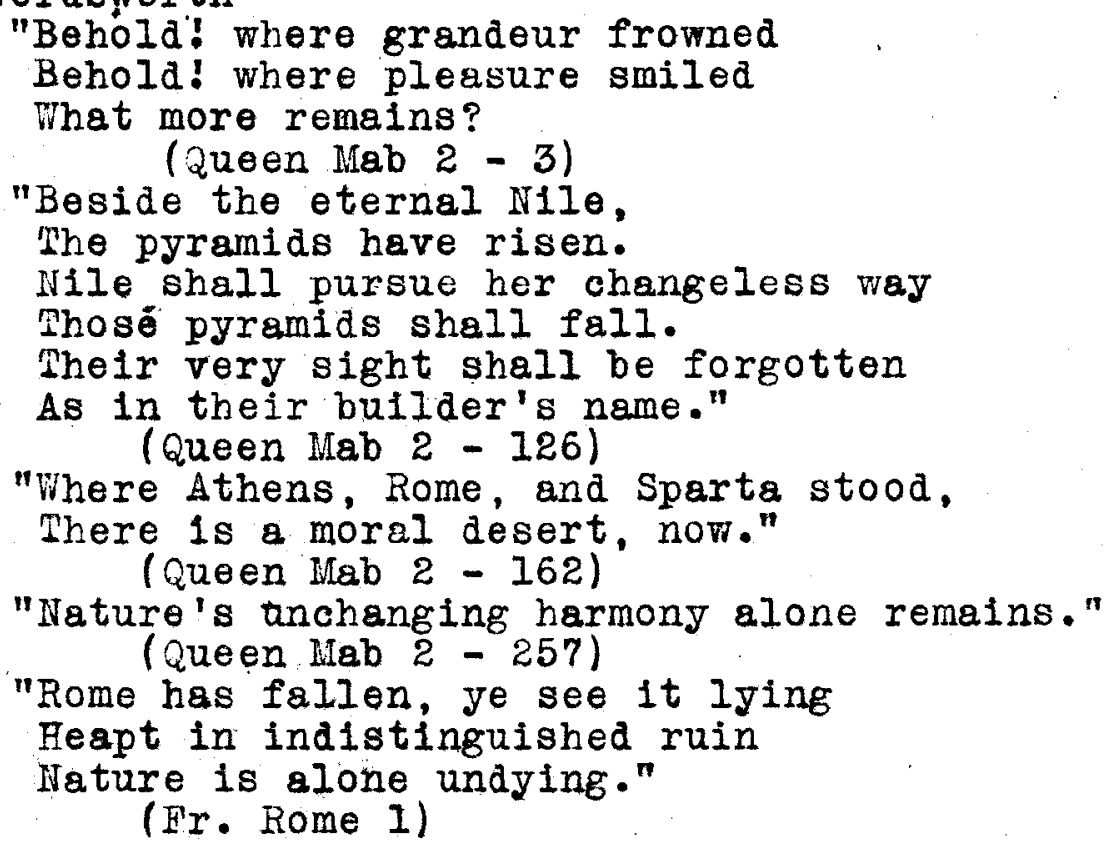

Iike Wordsworth and Coleridge, he felt the necessary part that silence and solitude play in the plan of the universe. To him they were essential, at times, although he loved mankind.

"Silence and twilight unbeloved of man

Creep hand in hand from yon obseurest glen." (Summer LV. 5)

"Twilight ascending slowly from the east,

Entwined in duskier wreath - his braided locks

o'er the fair front and radiant eyes of day. Night followed clad with stars."

\section{(Alastor 337)}

One feels the silence in these lines. In the "Spirit of Solitude" one feels Shelley's joy in loneliness, but the shadow of death 
saddens him. The solemn reverence for the beauties of nature and his almost holy love for her and her lonely spots are best expressed in this poem but in such a sad vein as to render it almost depressing. We feel always in Shelley the unsatisfied longing for the harmony of truth and beauty, the everlasting search for the key-note to the things that are unfathomable.

Shelley must have felt, as he wrote, as a part of nature, regarding earth, ocean, air - "the great trio" as "his beloved brethren", else he could not have made all nature live for us as he does in his wonderful dramatic way. All phases of nature, for him, are personified. What could be more aramatic -

"O wild West Wind, thou breath of Autumn's being, .

Thou from whose unseen presence the leaves aead

Are driven like ghosts from an enchanter fleeing." (Ode to $W$. Wind 1 - I)

"Driving sweet bias like flocks to feed in air." (Ode to $\mathrm{W}$. Wind $1-2$ )

"Wild Spirit which art moving everywhere

Destroyer and preserver, hear o hear."

(Ode to $W$. Wind 1 - 13)

All the "Queen Mab" nature is personified, dramatized. The fairy addresses the stars, the moon, the ocean, ss though they were to him living thinking human beings. Shelley must, at times, have felt them so or he would not have been able to make it all so real.

"Prometheus Unbound" is. just one great personification of only a man very close to her heart could have written it.

Just so "the Skylark". We have to rise with the bird, we cannot help it. We can hear the "rain of melody", the "flood of rapture so divine". He makes us, however, feel the difference between man and nature, the full ignorant joy of the bird that ne'er knew "love's sad satiety" and man who looks before and after and "pines for what is not". Even in man's laughter, there is pain, his sweetest songs are thoss of sadness, but he, like Nordsworth, tells us we can hear, if we only listen, the happiness of other forms of nature and become happy.

Shelley sings of the same things in nature that Wordsworth and Coleridge do but differently. His touch is that of the aramatist. Fe makes the to us inanimate objects, live; not in Wordsworth's simple, natural way, nor Coleridge's bold beautiful way, but with a soft imagery that makes us see not only the form of nature but weaves a little story about it, sonetimes with a simple word.

He uses adjectives of color, especially gold and purple. 
Wordsworth's simple statements do not satisfy his great love of beauty and grandeur. His thoughts soared just a little higher than Wordsworth's as his skylark does, even though his heart is still upon' the ground.

He makes the cloud "to laugh" as she passes.by and "to sleep in the arms of the blast" or "to bask in heaven's blue smile" or "rest in her airy nest as still as a brooding love" or hang "like a roof with the mountains for columns." One feels and knows, because he says it so convincingly that this cloud may change but never die.

Here, he uses a single adjective and gives us a plcture and a story if we have not the "soul of a clod." -

$$
\begin{aligned}
& \text { "The Iradad-Iike lily of the vale." } \\
& \text { (Sensitive PI. I - 2) } \\
& \text { "Starry river-buds." } \\
& \text { (Sensitive PI. I - 46) }
\end{aligned}
$$

He speaks of the daisy as the "castellated flower that never sets." (The Question - 2-2) Again - -

$$
\begin{aligned}
& \text { "The point of one white star is quivering still } \\
& \text { Deep in the orange light of widening moon } \\
& \text { Beyond the purple mountains." } \\
& \text { (Prom. } 2-1-17)
\end{aligned}
$$

We see, in this, the star shining white against the deep blue of the sky contrasted with the orange of the moon and the purple of the mountains. The one word "quivering" and the adjectives of color make it live.

"The waves are dancing fast and bright." (st. Dejection $1-2$ )

We feel and see them going up and down in joy, and gleaming.

No poet has written more about the flowers, especially the little simple ones. He does more than wordsworth with them. We see their color and feel their atmosphere.

"And the hyacinth purple and white and blue

Which flung from its bells a sweet peal anew

of music so delicate, soft and intense

It felt like an odor within the sense."

$$
\text { (Sensitive Pl. I - 25) }
$$

Who from such a description cannot see, smell and catch the message of the hyacinth? Wordsworth might have given us the message but not the odor and the color.

We feel and see all the flowers in "The Sensitive Plant". Shelley speaks of the "tender blue bells." (whe question 2 -4) We get a clear picture of the fragile little things from the two 
words "tender" and "blue".

Again he mentions the "falnt oxslips". (The Question 2-3) His spirit of love always wove a history into the descriptions of the little blossoms of earth.

"And the wand-like lily which lifted up

As a Naenad, its moonlight-colored cup

Till the fiery star which is its eye

Gazed thro" clear dew on the tender sky." (Sensitive plant I- 33)

The underscored words speak volumes. He had also, a great love for the wind and makes, as always Shelley does, a living breathing creature of it.

"The light winds which from unsustaining wings

Shed the music of many murmurings."

(Sensitive PI. I - 78)

"Wild Spirit which art moving everywere

Destroyer and preserver, hear o hear!"

(ode to West W. I - 13)

- Shelley has the real poet's love of the moon and night.

"The broad and yellow moon

Shone dimly thro.' her form -

That form of faultiess symmetry."

Again -

(Queen Hab 1 - 79)
"Through which the moon's unclouded grandeur rolls." (Queen Mab 4 - 6)
"When the moon over ocean's line
Is spreading the locks of her bright gray hair." (Fr. Song 3)
"Blue isles, and snowy mountains wear
The purple moon's transparent might."
(St. Dejection 1 - 3)
"The orbed malden with white fire laden
Whom mortals call the moon."
(Cloud 45)

He had, also, the love of the sea natural to his race. Whenever he mentions even the terror and might of it, we feel that it is very dear to him.

"I see the Deep's untrampled floor

With green and purple sea-weeds strown."

(st. Dejection $2-1$ )

"I see the waves upon the shores

Iike light dissolved in star showers, thrown."

(St. Dejection 2 - 4) 
So, we find Shelley singing of the little flowers, birds, insects, the mighty or gentle wind, the fierce or calm ocean, the mighty peaks of the Alps, the ice, the snow, and almost every phase of nature, regarding each one as his brethren and. everything as a part of the great whole. 
KEATS AND NATURE.

$--000--$

"Linger awhile upon some bending planks

That lean agalnst a streamlet's rushing banks And watch intently Nature's gentle ways."

\section{(I stood - 6)}

Keats, well-loved by all poets, especially by those of his own era, has been termed "the bard of beauty", though it is doubtful whether any one poet deserves that distinction, as each presents beauty to us in a different way.

Iike all the poets of this group, he loved the flowers, the sea, the moon, the stars, the birds, insects, and humanity and sings of them all. Wordsworth's simple words, however, never could have sufficed for Keats, nor yet Coleridge's clear pictures, nor even Shelley's imagery. Keats is so full of sense impressions that we can smell the flowers, taste the luscious fruit, and hear the wind murmuring in the trees. Iike Wordsworth, he was alert to the least little sight or sound in nature, so much so that with the help of his wonderful inagery, his reader's senses are awakened just as his were and we have before us a glorlous world that some of us have never seen or heard or smelt before. Here are some examples: " - - - - Every sense

Filling with spiritual sweets to plentitude

As bees gorge full their celis."

(Endymion III)

" - - Raln-scented eglantine

Gave temperate sweets to that well-wooing sun." (Endymion I - 5)

- To swell the gourd and plump the hazel shells With a sweet Kernel."

(To Autumn I)

"WInd hush'd, cool-rooted flowers, fragrant-eyed, Blue, silver-whito and budded lyrian."

(Ode to Psyche.)'

"The morn was clouded, but no shower fell, 'ho' in her lids hung the sweet tears of hay." (Ode to Indolence 5)

"I saw an arbour with a drooping roof of trellis vines, and bells; and larger blooms like floral censers swinging light in air."

$$
\text { (Hyp. A. V. 2) }
$$

" - - - - Cold springs had run

To warm their chilliest bubbles in the sun." (Endymion I - 5)

"So the unnumber'd sounds that evening stores the leaves The songs of the birds - the whispering of

The roice of waters - the great bell that heares "ith solemn sound." (Sonnet 4) 
One who reads this, must have no senses, if he hears not what the leaves are saying and what the waters are calling to one another. He cannot but feel the solemn spirit of the eventide. Again -

"So I straightway began to pluck a posey

of luxuries bright milky, and rosy."

$$
\text { (I stood - I) }
$$

"And filled are the fruit with ripeness to the core." (To Autumn I)

"As the jear grows lush in juicy stalks." (Endymion 1 - 3)

His magical use of the words ripeness, juicy and lush speak more to us than volumes of description.

Keats has a wonderful way of using adjectives and nouns that are simple in themselves, but draw vivid sense pictures for the reader.

"Our feet were soft in flowers." The one word "soft" is the key-note to the whole picture. "O for a beaker full of the warm south." (Ode to a rightingale 1)

Nature lived for Keats even more vividly than she did for Coleridge and Shelley; so he constantly personifies all parts of nature in his poetry. I do not believe that one who is not close to the heart of nature can personify her different parts in a convincing way.

"The sun when flrst he kist away the tears That filled the eyes of morn."

(Sonnet to B.G. 3)

Again -

"Open afresh your round of starry folds

Ye ardent marigolds."

- (I stood 4)

"E'en like the passage of an angel's tear

That falls through the clear ether silently."

(Sonnet 10)

One seems to hear the tear fall.

Iike all the other poets of this group, Keats needs nature as a relief and a joy not found in humanity. Beauty he must have. As Shelley, he worships it and finds his greatest consolation in it. "A thing of beauty is a joy forever" seems to be the slogan of these two poets. It need not be a big thing but just natural and beautiful. Their conceptions of beauty however, differed. In Shelley's "Hym, to Intellectual Beauty" and Keats' "Sleep and Poetry", we find this difference most strongly emphasized. Keats in his conception seems to dwell a little nearer to the earth. He wanted in his poetry to have the earthly beauties. He writes "- - - - - - - - The blue
Bar'd its eternal bosom, and the dew
Of summer nights collected still to make
The morning precious : beauty was awake!" (Sleep and Poetry - 8) 
"And they shall be accounted poet kings

Who simply tell the most heart-easing

0 may these joys be ripe before I die."

(Sleep and Poetry - II)

Keats seems in his poem to long to ease the senses with his verse, to catch a vision that would live in the hearts of men and ease them.

Shelley seemed to be grasping always after something higher, something that he cannot quite catch and hold but keeps striving after. He speaks of it as -

"The awful shadow of some unseen power

Floats tho' unseen amongst us."

(Hymn to I.B. - I)

"It vigits with inconstant glance

Each human heart and countenance."

(Hymn to I.B. - 2)

$\therefore$ "Spirit of Beauty. that dost consecrate

With thine own hues all thou dost shine upon

of human thought or form."

(Hymn to I.B. - 2)

"What thou - 0 awful Ioveliness

Wouldst give whate'er these words cannot express." (Hymn to I.B. - 6)

Shelley seems to believe that Beauty of a type so high that it is almost inconceivable to one who cannot soar, will redeem the world and make man immortal and omnipotent.

They both feel their spirits linked with those of the great poets who have gone before and try to catch the spirit of the beauty contained in the poetry of each; but just as the nature poetry of each differs, so the conception of beauty caught and held seems to have differed for every great poet. Shelley's seems to have been most intangible since he seems always to have soared higher than other poets in his thoughts. However, although we cannot quite catch Shelley's vision, we have to believe with Keats -

"Beauty is truth, truth beauty - that is all

Ye know on earth and all ye need to know." (Ode to Grecian Urn. 5)

Keats loved humanity, however. He considered human life as a part of nature but higher.

"Yes, I must pass them for a nobler life

Where I may find the agonies, the strife

of human hearts."

$$
\text { (Sleep and Poetry - 6) }
$$

Iike Wordsworth, he feels the difference between man and bird. This is best brought out in his "Ode to the Nightingale" "Thou wast not born for death, immortal bird

No hungry generations tread thee down."

Rich and poor are alike to the birds. Nature is impartial.

full of sorrows but his life is higher. 
We feel that Keats was very near to country IIfe and the rude things that compose it but his imagery is never laid aside even for the rudest phases. His shepherds are ideal ones. They seem to have a glamour about them that makes it impossible for us to realize that his shepherds and Wordaworth's are the same simple folk.

Iike all deep thlnkers, Keats seems to have realized the briefness of human life, compared to that of nature, although he does not bring out this point very definitely in his poetry. We gather. that impression from it as a whole, however. Fere are some of the references to that subject -

"Stop and consider! Iife is but a day

A fragile dew drop on its perilous way

From a tree's summit."

(Sonnet - 10)

"Bright star would I were steadfast as thou art." (Sonnet - 1)

"And still they were the same bright petient stars." (Hyperion 1 - 12)

"Thou wast not born for death, immortal bird:

The voice I hear this passing night was heard

In ancient days by emperor and clown."

(ode to vightingale.)

In writing of the sea -

"It keeps eternal whisperings around

Desolate shores."

(S. to Seg.)

Keats seems to have been so busy however, seeing the beauty about him that he had not time to meditate on the "sting of perishable things" as Wordsworth did.

Silence was with Keats one of the necessary factors in the universe.

" - - - Then there crept

A little stir among the leaves

Born of the very sigh that silence heaves."

(I stood - I)

"How silent comes the water round that bend."

(I stood - 6)

"Where is a charm in footing slow across a

silent plain."

$$
\text { (Iines - I) }
$$

Of course, Keats young and ardent, sad and glad, loved

Dian in all her beauty. He, it is, that addresses her -

"O Maker of sweet poets."

(I stood - 7 )

"The must I praise above all other glories."

(I stood - 7) 
"What is there in thee, Hoon! that thou shouldst move

Hy heart so potently?"

(Endymion $3-4$ )

"One moon with alteration slow, had shed

Her silver seasons four upon the night."

(Hyperion - 4)

"Or by the moon lifting her. silver rim

Above a oloud and with a gradual swim

coming into the blue with all her light." (I stood - 7)

The following gives us some idea of his love of the sea and his joy in 1t:

"O ye! who have your eye-balls vex'd and tired

Feast them upon the wideness of the sea." (Sonnet on Sea.)

He thinks that one who has had too much of "cloying melody" would enjoy the noise of a cavern by the sea.

"Ocean, too, with all its solemn noise."

(Hyperion - 3)

"The ocean with its vastness, its blue green,

Its ghips, its rocks, its caves, its fears."

- (Sonnet to B.G. Iine 5)

All the little simple flowers are as dear to Keats as to

Wordsworth. He, however, loved the "gentle musk-rose most than all".

"The coming musk-rose full of dewey wine."

(Ode to Nightingale - 5)

"I saw the sweetest flower wild nature ylelds

A fresh-blown musk-rose."

(Sonnet - 5)

"I thought the garden-rose it far excelled."

"A bush of lay elowers with the bees about them."

(I stood - 2)

"Here are sweet peas on tip-toe for a flight."

(I stood - 5)

" - A tuft of primroses

o'er which the wind may hover till it dozes."

(I stood - 7)

Keats interprets for us the song of the lark and the nightingale and even the grasshopper and the cricket come in for their share of appreciation. He writes a sonnet on the grasshopper and the cricket in which he says -

"The poetry of the earth is never dead."

(Sonnet - 15)

In writing of the grasshopper -

"He takes the lead

In surmer's Iuxury."

(Sonnet - 15) 

"The cricket's song in warmth increasing ever."

Each little creature about us has his song.

"The merry lark has pour'd

His early song against yon breezing sky." (Endymion 1 - 9)

"Bright as the humning bird's green diadem

When it ilutters in sunbeams that shine through a fountain."

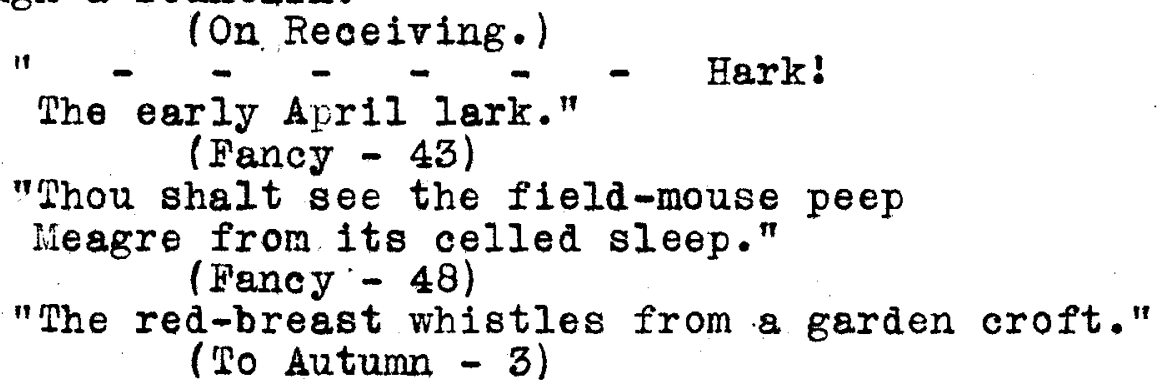

We feel that if Keats had lived longer, ho would have learned much from life and taught us much; but for a man who had not yet reached his twenty-eighth birthday when death overtook him, he did more than his share towards the world's literature. He, at least, awakens in the hearts of all who read his work -.

"The beauties of nature

They must be always with us or we die!"

(Enaymion 1 - 2)

The following words of his seem to characterize Keats young and full of joy and sorrow as he was.

"I love to mark sad faces in fair weather

And hear a merry laugh amid the thunder."

(Fragments - Iine 5)

"Dancing music, music sad

Both together, sane and mad!"

(Fragments - Line II)

"Iaugh and sigh and laugh again

Oh! the sweetness of the pair!"

(Fragment - Iine 14) 
BYRON AND NATURE.

$--000--$

"Oh: that the desert were my dwelling place

With one fair spirit for my minister

That I might alI forget the human race."

$$
\text { (c.H. } 4-187 \text { ) }
$$

The last poet in this group, Iord Byron, living the conventional artificial life that he did, cannot be truly said to have loved nature for herself as did Wordsworth, Shelley, Keats and Coleridge.' He loved her only in certain phases. The big, wila, wonderful parts of her, - the storm, the sun, the Alps, and most of all, the sea appealea to Byron. He needed nature more than any of these poets but her simplest beauties would not suffice. So wila and fast was his life among men that he sought nature to bring him back to a normal state. Because he had lived so violently the social side of life only the wilder side of nature sufficed to interest him and help him back to a normal state. Byron was always either Iiving life to its utmost among men, or seeking to get as far away from mankind as possible. No poet has assumed nore of an anti-social position in his writings than Byron and yet, he never loses himself in nature so completely that he entirely forgets mankind. We cannot imagine his living quietly in the country in Old England as Wordsworth or Coleridge. He had to have an audience. In spite of his assurances to the contrary, we are compelled to feel all the time that mankind fascinated him and nature was merely a relief from too much man. We cannot help feeling that if he had lived a little nearer to the purer type of man away from cities and temptations at least part of the time, that he might have had less of an anti-social attitude even in his imagination.

He seems to me to have used nature in his writings just as he did in his life as a sort of a background whereon to place mankind. He writes no poem to the lark or the night-in-gale, nor is the simple cowsilp or the star-shaped daisy even mentioned in his writings. We wonder if he really knew them by their names or if they were too small and insignificent a part of nature's whole. The only flower he really names is the violet. He writes -

"But now the wild flowers round them only breathe." (C.H. $1-22$.

Keats would have told his reader what oolor they were, would have had one smelling them, seeing, feeling each particular one. Shelley could never have resisted adding a bit of speaking description. "Sweet was the scene, yet soon he thought to flee More restless than the swallow in the sky."

$$
\text { (C.H. } 1-27)
$$


Just so Byron. He saw nature's beauties, but was in such a hurry to pass on to the next thing in hand that unless they spoke loudly enough to him he could not hear them. Men, their doings, and ways really concerned him although he truly thinks they do not. Had not nature stepped in and saved Byron for us, we feel that he could not have written poetry that would have endured. He was one with the lightning that he loved, never slow and sure but flashing here and there.

His attitude towards mankind is best explained by the following in speaking of the hermit -

"Sigh forth one wish that such had been his lot

Then turn to hate the world he had almost forgot." (C.H. $2-27$ )

however.

We know he could not have survived long in such a life,

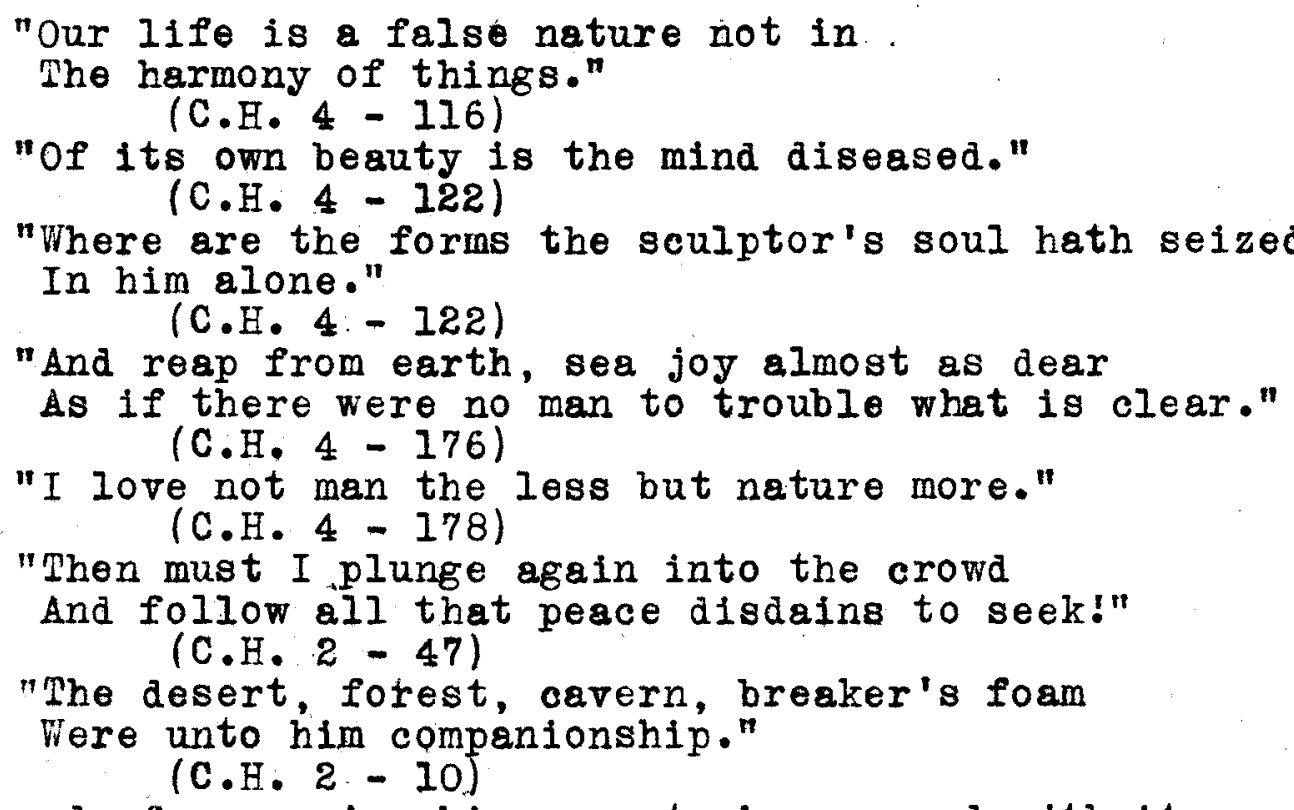

Always the need of companionship except when gorged with it.

"But in man's dwelling he became a thing

Restless and worn, stern and wearisome."

(C.H. $3-15$ )

"Is it better to be alone

And love earth only for its earthly sake?"

(C.H. $3-7 \mathrm{I})$

We cannot feel that he loved Mother Earth for her own sake. There is something lacking. He does not get close to her heart. He loves her simply as a relief and a contrast to mankind.

"I can see nothing to loathe in nature save to be

A link reluctant in a fleshly chain." (C.H. 3 - 72) 
He never becomes so lost in nature that he is able to put man completely from his mind.

"Are not the mountains, waves, and skies a part

Of me and my soul as I of them?"

(C.H. $3-75)$

"Spain's realms appear whereon her shepherds tend

F'locks whose rich fleece right well the trader knows." (C.H. I - 3I)

It would never have occured to Wordsworth to think of sheep on the hill-side and the price of their wool, in the same thought, let alone in a line of a poem.

Again -

"o'er vales that teem with fruits, romantic hills

(Oh, that such upheld a freeborn race.)"

Wordsworth would have told us of the little bits that composed "the romantic hills" and Shelley, Coleridge and Keats would have made us see them even as each of them did in his own sweet way.

Byron does not write nature poetry although he has to have nature in it. His descriptions however of the wild terrible parts of nature are wonderful. To him lit. Blanc seemed to sing no paean to God but -

of the storm he writes -

"The throned Eternity in icy balls

of cold sublimity where forms and falls

The avalanche - the thunder-bolt of snow." (C.H. $3-42)$

"o night

And storm and darkness, ye are wondrous strong

Yet lovely in your strength."

(C.H. $3-92$ )

We believe that this is genuine because we feel he really joyed in the boisterous storm.

"Then let the winds howl on: their harmony

Shall, henceforth, be my music."

$$
\text { (C.H. } 4 \text { - IO6) }
$$

"Dear nature is the kindest mother still

Oh! she is fairest in her features wild

Where nothing polished dares pollute her path

To me by day or night she ever smiled

Though I have marked her when none other hath

And sought her more and more, and loved her best

in wrath."

$$
\text { (C.H. } 2 \text { - 37) }
$$

When Byron writes of the sea, however, we feel that he is at his best; for he seems to have truly loved the ocean in all its different aspects. 
"Where rolled the ocean, thereon was his home." (C.H. 3-13)

"He that hath salled upon the dark blue sea

Has viewed at times, I ween, a full fair sight." (C.H. $2-17$ )

He tells us that when he gazed into the water where Dian was reflected his soul forgot the present, her schemes of Hope and Pride and flew back over long years finding something worth a tear.

"As winds come lightiy from the west

Hissing, not ruffling, the blue deep's serene." (C.H. 2 - 7O)

"Once more the waters! yet once more!

And the waves bound beneath as a steed

That knows his rider. Welcome to their roar!" (C.H. 3 - 2)

We feel the joy in that.

Flung from a rock, on ocean's foam to sail

Where'er the surge may sweep, the temptest's

breath prevail."

$$
\text { (c.H. } 3-2 \text { ) }
$$

"And I have loved thee, Ocean.!"

$$
\text { (C.H. } 4-184 \text { ) }
$$

"Roll on thou deep and dark blue ocean - roll!"

$$
\text { (C.H. } 4-79 \text { ) }
$$

He is glad that man has no control over the ocean.

ments, rock-built oities, monarchs are but toys for the deep.

The sea ohanges not with time -

"Boundless, endless, and sublime

The image of Eternity."

"Time writes no wrinkle on thy brow." (C.H. $4-182$ )

"Oh! who can tell, save he whose heart hath tried

And danced in triumph o'er the water wide

The exulting sense."

(Corsair 1 - 1)

These are some of the most striking of his references to the sea.

His tribute to the sun in "Manfred" is one of his best "Glorious orb, the idol.

Of early nature and the vigorous race

of undiseased mankind." etc.

(Manfred Act. 3 - 2)

He tells the sun God chose it for his shadow and put it in the sky as his first minister, the center of all the stars, to rule the reasons, to shine and set in glory. 
The moon does not seem to have come in for her share of admiration among nature's wonders. She is always mentioned rather casually.

$$
\begin{aligned}
& \text { "The moon is up; by Heaven, a lovely eve! } \\
& \text { Long stregms of light o'er dancing waves expand." } \\
& \text { (C.H. 2- 2I) }
\end{aligned}
$$

How different to Wordsworth, Keats, Shelley, no one of whom could have resisted the possibilities of the moon.

"And thou didst shine, thou rolling moon upon

All this and cast a ide and tender light."

(Manfred Act. $3-4$ )

When Byron does undertake to describe a single small part of nature he does it well.

"An iris sits amidst the infernal surge Like Hope upon' a death-bed."

$$
\text { (C.H. } 4-72 \text { ) }
$$

His descriptions of the Rhine seem to be genuine and beautiful but are so interwoven with the history of man and his doings that we feel he has merely used "the glorious Rhine" as a spool on which to wind the threads of history, using nature as usual, when he needs her.

As the other poets do he feels the eternity of nature as compared with man's three-score years and ten.

"----like yonder Alpine snow

Imperishably pure beyond all things below."

$$
\text { (C.H. } 3-47 \text { ) }
$$

"State falls, arts fade - but

Nature doth not die."

$$
\text { (C.H. } 4-3 \text { ) }
$$

Byron loved solitude, evening, silence just as Wordsworth, Keats, Shelley and Coleridge did but not for itself alone as they did but as a relief from too much "man". Twilight and night seemed to have soothed his wild nature more than anything else could.

"I linger yet with Nature, for the night

Hath been to me a more familiar face

Than that of man."

(Manfred Act. $3-4$ )

"And this is night - Most glorious night!

Thou wert not made for slumber!"

(C.H. 4 - 93)

The following is as beautiful as anything Byron has written - 
"When the last sunshine of the day

In summer's twilight weeps itself away

Who hath not felt the softness of the hour

Sink on the heart as dew upon the flower?

(Man. on Death of Sheridan 1)

"To sit on rocks to muse o'er flood and fell

Where things that own not man's dominion dwell

Alone o'er steeps and foaming falls to lean

This is not solitude; 'tis but to hold

Converse with Nature's charms, and view her stores unrolled."

(C.H. $2-25$ )

"But midst the crowd, the hum, the shock of men

And roam along the world's tired denizen

With none to bless us, none whom we can bless

This is to be alone, this, this is solitude!"

(C.H. $2-26$ )

"If from society we learn to live

'Tis solitude should teach us how to die."

(C.H. $4-33$ )

Byron seems, in his youth, to have recognized God's hand

in nature's workings: He sees God's law in her."-

"Thy laws in nature's works appear."

(Prayer of Nature $10-2$ )

He writes so little along this strain however, that one cannot be sure just what he thought of God and immortality, though he seems to have considered God as apart from nature not nature as Shelley dia

"Alone - man with his maker must strive."

(C.H. $4-33$ )

"My altars are the mountains and the ocean

Earth, air, stars - all that springs from the great "Whole",

Who hath produced, and will receive my soul." (C.H. $4-10)$

Shelley's idea which Byron has caught.

We really feel that Byron was his own God or else the big, wild wonderful parts of nature - maybe the sea, served as a kind of God to him.

One of the great true beautiful characteristics of Byron was his love for Greece and nature as found there. Whether this might be termed part of a nature subject, I know not; but I do know that some of his most beautiful descriptions are those of the land he loved, although we well know we should not have had them if Greece 
had not once been the land she was. rarely seen."

"Yet, in fancied Attica, some lovely dales are

$$
\text { (C.H. } 2-46)
$$

In Childe Harold, when he approached Greece on his voyage, he writes -

"But when he saw the evening star above

He felt or thought he felt no common glow."

(C.H. 2 - 4 I)

"Epirus's bounds recede, and mountains fail,

Tired of up-gazing still, the wearied eye

Reposes gladiy on as smooth a vale

As ever sprang yelad in grassy dye."

(C.H. $2-54$ )

We feel his nature here is natural. He aotually. Ioves her but because she is a part of his loved Greece.

"Fair Greece! sad relic of departed worth

Immortal, though no more, though fallen, great!" (C.H. $2-52$ )

"Yet are thy skies as blue, thy crags as wild

Sweet are thy groves, and verdant are thy fields

Thine olive ripe as when Minerva smiled

And still his honied wealth Hymethus yields

There the blithe bee his fragrant fortress builds

The free-born wanderer of the mountain air,

Art, Glory, Freedom fail, but Irature still is fair."
(C.H.2 - 87)

He tells us that Go'd made Greece beautiful but man has marred i.t into wilderness and trampled on the flowers. He curses the tyrants that destroy.

"The isles of Greece, the isles of Greece!

Eternal summer gilds them yet

But all, except their sun, is set."

(Don Juan 3-86)

So we find Byron loving the big wild parts of nature because he might have loved her every phase, if he had not been rushing so from one place to another, one thing to another, all the time. He writes in one poem -

"The scene was savage but the scene was new." (C.H. $2-43$ )

We cannot help believing that if Byron had lived very near to nature's heart the greater part of the time, instead of wild among men that he seemed at times to hate, he would have been truer. His poetry would have been deeper and minus that flippant tone which so often grates on the ear. His views of life would have been saner and he would have been more certain of the law of right and wrong had he studied nature's book where all may read. 


\section{CONCLUSION.}

$$
-000-
$$

In conclusion then, Nature has given us these five poets, each great in his own way - Wordsworth in his sweet simplicity and naturalness; Coleridge in his wonderful pictures; Shelley in his beautiful imagery and love of intellectual beauty; Keats in his telling descriptions and sense impressions; Byron in his wild joy in the big unusual parts of nature. As long as the English tongue and race endure. I believe these poets will continue to awaken in the hearts of men a deeper truer love for nature herself and through this love bring man unconsciously a little nearer to his God, somehow the maker of it all.

$$
\begin{aligned}
& \text { "Thus ye teach us, every day } \\
& \text { Wisdom, though fied far away, } \\
& \text { Bards of Passion and of lirth } \\
& \text { Ye have left your souls on earth! } \\
& \text { Ye have souls in heaven too, } \\
& \text { Double-lived in regions new!" } \\
& \text { (Keats - ode) }
\end{aligned}
$$

